\title{
Thyroid Cancer Pathologic Distant Metastasis TNM Finding v6
}

National Cancer Institute

\section{Source}

National Cancer Institute. Thyroid Cancer Pathologic Distant Metastasis TNM Finding v6. NCI Thesaurus. Code C60796.

A pathologic finding about one or more characteristics of thyroid cancer, following the rules of the TNM AJCC v6 classification system as they pertain to distant metastases. TNM pathologic distant metastasis findings are based on clinical findings supplemented by histopathologic examination of one or more tissue specimens acquired during surgery. 